\title{
Effects of inulin on rumen metabolism in vitro
}

\author{
Hakan ÖZTÜRK \\ Department of Physiology, Faculty of Veterinary Medicine, University of Ankara, Ankara-Turkey.
}

\begin{abstract}
Summary: The objective of this study was to investigate the effects of inulin [as topinambur (Helianthus tuberosus L.) powder] on in vitro rumen fermentation of diets containing hay and pelleted concentrate for sheep (approximately 60:40\%) in artificial rumen (the RUSITEC system). The RUSITEC system consisted of six fermentation vessels. Topinambur powder was added at levels of $0.2,0.4,0.6,0.8$ and $1.0 \mathrm{~g} /$ day into the five fermentation vessels while the last one served as a control (without having any topinambur powder). The results showed that the addition of topinambur powder up to $1.0 \mathrm{~g} /$ day reduced $\mathrm{NH}_{3}-\mathrm{N}_{\text {concentration }}$ significantly $(\mathrm{p}<0.05)$. However, the other basal parameters of rumen fermentation ( $\mathrm{pH}$, short-chain fatty acid production and organic matter digestibility) examined in this study were not significantly affected by the addition of topinambur powder. These results indicated that inulin has the potential to improve ruminal nitrogen utilization.
\end{abstract}

Key words: Helianthus tuberosus L., inulin, prebiotic, rumen, topinambur powder.

\section{Inulinin rumen metabolizması üzerine in vitro etkileri}

Özet: $\mathrm{Bu}$ araştırmada, kuru ot ve koyun konsantre pelet yeminden oluşan (60:40) bir rasyonun in vitro fermentasyonunu, inulinin [yer elması (Helianthus tuberosus L.) unu formunda] ne şekilde etkilediğinin ortaya konması amaçlanmıştır. Bu amaçla altı fermenterden oluşan bir RUSITEC sistem kullanılmıştır. Fermenterlerden beşine yer elması unu 0.2, 0.4, 0.6, 0.8 ve 1.0 g/gün dozlarında ilave edilirken, sonuncusuna herhangi bir ekleme yapılmayıp kontrol fermenteri olarak kullanılmıştır. Yer elması ununun 1,0 g/gün dozuna kadar yapılan ilavesi amonyak konsantrasyonunu azaltırken $(\mathrm{p}<0.05)$, rumen metabolizmasının diğer temel parametreleri olan $\mathrm{pH}$, günlük uçucu yağ asitleri üretimi ve organik madde sindirilebilirliğinde istatistiksel bir değişikliğe yol açmamıştır. $\mathrm{Bu}$ araştırmanın sonuçları inulinin ruminal azot değerlendirilebilirliği üzerine olumlu etkilere sahip olabileceğini göstermektedir.

Anahtar sözcükler: Helianthus tuberosus L., inulin, prebiyotik, rumen, yer elması unu.

\section{Introduction}

For many years, ruminant nutritionists and microbiologists have been interested in manipulating the microbial ecosystem of the rumen to improve production efficiency by domestic ruminants. Much of the research in the past 20 to 25 years has focused on the effects of antimicrobial compounds on ruminal fermentation. Ionophore antibiotics, such as monensin and lasalocid, have been used extensively to improve rumen fermentation (1). Due to the emergence of microbes resistant to antibiotics that are used to treat human and animal infections, the European Commission decided to phase out, and ultimately ban since 1 January 2006, the marketing and use of antibiotics as growth promoters in animal feed. For this reason, attention has recently shifted to natural feed additives as a safe means for modifying ruminal fermentation. Because prebiotics are used for a long time in human medicine for improving intestinal microbial balance, it would be of interest to examine the suitability of inulin as a feed additive in ruminant nutrition.
Inulin is a polydisperse non-starch polysaccharide naturally occurring as a storage carbohydrate in some 36,000 plant species. The main sources of inulin are chicory and topinambur (Helianthus tuberosus L.). Inulin consists of chains of fructose units coupled by $\beta(2,1)$ bonds most often (though not always) terminated by a single glucose moiety. The degree of polymerization (dp) of inulin ranges from 2 to 60 and above and depends mainly on the type of plant from which it is isolated (3, 8). Due to their $\beta(2,1)$-bonds, inulin is resistant to enzymatic hydrolysis in the upper gastrointestinal tract of humans and monogastric animals. When undigested inulin reaches the colon it is fermented by colonic microflora, which causes selectively stimulating the growth of certain groups of bacteria. Therefore, inulin is considered the archetypal prebiotic $(6,15,19,21)$. A prebiotic is defined as "a nondigestible food ingredient that beneficially affects the host by selectively stimulating the growth and/or activity of one or a limited number of bacteria in the colon and thus improves host health" (7). Inulin is used successfully in monogastric 
animals, but not in ruminants. The process of fermentation that occurs in the colon of monogastric animals is essentially identical to that occurs in the forestomachs of ruminants. At present, few studies have investigated the direct effects of inulin on rumen metabolism.

The aim of the present experiment is to evaluate the effects of inulin on rumen metabolism in vitro.

\section{Materials and Methods}

\section{Incubation technique}

The study was carried out using the rumen simulation technique (RUSITEC) described by Czerkawski and Breckenridge (5). The experiment consisted of 6 plexiglass 1-L vessels (fermentors) maintained at constant temperature $\left(39^{\circ} \mathrm{C}\right)$. The nominal volume in each vessel was $750 \mathrm{~mL}$. The vessels were inoculated on d 1 with liquid (gauze-filtered) and solid rumen contents taken from 2 rumen cannulated adult donor sheep that were maintained on a diet of hay and concentrates. Animals had free access to hay, water, and a vitamin-enriched salt lick. The same dietary components were used for in vitro fermentation trials. The chemical composition of the experimental diet is presented in Table 1 .

Table 1. Chemical composition of the diets (\%). Tablo 1. Rasyonun kimyasal içeriği (\%).

\begin{tabular}{lrc}
\hline Ingredient & Hay & Concentrate \\
\hline Dry matter & 93.94 & 90.48 \\
Crude protein & 7.27 & 15.96 \\
Crude lipids & 0.88 & 2.32 \\
Crude fiber & 27.59 & 10.49 \\
N-free extract & 46.01 & 43.36 \\
Total ash & 6.13 & 8.83 \\
\hline
\end{tabular}

Each vessel was loaded with 2 nylon bags (pore size, $150 \mu \mathrm{m}$ ). At the start of the trial, one bag was filled with $80 \mathrm{~g}$ of solid rumen contents (fresh weight) and the other with the daily diet, a mixture of $5 \mathrm{~g}$ of hay and $4 \mathrm{~g}$ of pelleted concentrate. The nylon bag with solid rumen contents was replaced after $24 \mathrm{~h}$ of incubation with a bag containing the diet. The feed bag was changed after $48 \mathrm{~h}$ so that 2 bags were always present. This gave a retention time of $48 \mathrm{~h}$ for feed. When the bag was being changed, the vessels were flushed with nitrogen to maintain anaerobic conditions. The liquid flow through the vessels was maintained by continuous infusion of a buffer solution of $\mathrm{pH} 8.12$ with $307 \mathrm{mosm} / \mathrm{L}$ at a rate of 750 $\mathrm{mL} / \mathrm{d}$. The buffer composition is presented in Table 2 .
Table 2. Chemical composition of the buffer solution ( $\mathrm{mmol} / \mathrm{l})$. Tablo 2. Tampon solüsyonun kimyasal içeriği (mmol/l).

\begin{tabular}{|c|c|}
\hline Ingredient & \\
\hline $\mathrm{NaCl}$ & 8.04 \\
\hline $\mathrm{KCl}$ & 7.65 \\
\hline $\mathrm{CaCl}_{2} \cdot 2 \mathrm{H}_{2} \mathrm{O}$ & 0.22 \\
\hline $\mathrm{MgCl}_{2} \cdot 6 \mathrm{H}_{2} \mathrm{O}$ & 0.63 \\
\hline $\mathrm{NH}_{4} \mathrm{Cl}$ & 5.00 \\
\hline $\mathrm{Na}_{2} \mathrm{HPO}_{4} \cdot 12 \mathrm{H}_{2} \mathrm{O}$ & 26.20 \\
\hline $\mathrm{NaHCO}_{3}$ & 117.90 \\
\hline
\end{tabular}

\section{Experimental procedure}

In vitro incubation trial lasted for 18 days and was divided into three periods: an equilibration, a control and an experimental period. The first 8 days period represented an equilibration period (to achieve steady state conditions) and the following 5 days were used to determine basic parameters of ruminal fermentation under control conditions without addition of topinambur powder. The last 5 days served as the experimental period. In this last period topinambur powder was added at levels of $0.2,0.4,0.6,0.8$ and $1.0 \mathrm{~g}$ /day into the five fermentation vessels, while last one served as a control without having any topinambur powder.

For the investigation of inulin on rumen fermentation in vitro, topinambur powder (Lohmann Animal Health, Cuxhaven, Germany) was used as an inulin source. Topinambur (Helianthus tuberosus L.) is storing inulin in its tubers as energy providing compound. So the main carbohydrate in topinambur tubers is inulin, composing $80-90 \%$ of the solid content (18).

\section{Analytical procedures and samplings}

The $\mathrm{pH}$ values were measured daily in each vessel at the time of feeding using a $\mathrm{pH}$ electrode (Typ 408 and Pt 4805-S7/120, Mettler Toledo, Steinbach, Germany) connected to a Knick pH meter (digital pH meter 646, Knick, Berlin, Germany). Liquid effluent was collected daily and samples were taken for analyses of short-chain fatty acids (SCFA) and $\mathrm{NH}_{3}-\mathrm{N}$. The overflow flasks were placed into ice to stop microbial activity and preserve fermentation products. An aliquot of effluent was centrifuged at $40,000 \times \mathrm{g}$ for $20 \mathrm{~min}$ at $4{ }^{\circ} \mathrm{C}$. The resulting supernatant was acidified with $0.1 \mathrm{~mL}$ of $98 \%$ formic acid and then centrifuged at $4000 \times \mathrm{g}$ for $10 \mathrm{~min}$ at $4^{\circ} \mathrm{C}$, then it was analyzed for SCFA by gas chromatography (model 5890 II, Hewlett Packard, Böblingen, Germany) equipped with a $1.8 \mathrm{~m} \times 2 \mathrm{~mm}$ glass column packed with Chromosorb WAW (mesh $80 / 100$ ) with $20 \%$ neopentyl glycol succinate and $2 \%$ ortho phosphoric acid. Helium was used as a carrier gas with a flow rate of $25 \mathrm{~mL} / \mathrm{min}$. Injection port, detector, 
Table 3. Effects of topinambur powders on in vitro ruminal fermentation parameters. Tablo 3. Yer elması ununun in vitro ruminal fermentasyon parametreleri üzerine etkileri.

\begin{tabular}{lccccccc}
\hline & $\begin{array}{c}\text { Control period } \\
(\mathrm{n}=6)\end{array}$ & \multicolumn{5}{c}{$\begin{array}{c}\text { Experimental period } \\
(\mathrm{n}=1)\end{array}$} \\
& $0.0 \mathrm{~g} / \mathrm{d}$ & $0.0 \mathrm{~g} / \mathrm{d}$ & $0.2 \mathrm{~g} / \mathrm{d}$ & $0.4 \mathrm{~g} / \mathrm{d}$ & $0.6 \mathrm{~g} / \mathrm{d}$ & $0.8 \mathrm{~g} / \mathrm{d}$ & $1.0 \mathrm{~g} / \mathrm{d}$ \\
\hline $\mathrm{pH}$ & $7.06 \pm 0.04$ & $7.09 \pm 0.03$ & $7.06 \pm 0.03$ & $7.03 \pm 0.06$ & $7.06 \pm 0.02$ & $7.03 \pm 0.05$ & $7.05 \pm 0.05$ \\
Total SCFA (mmol/d) & $23.95 \pm 2.97$ & $23.46 \pm 1.92$ & $26.02 \pm 0.97$ & $24.48 \pm 2.21$ & $23.11 \pm 1.57$ & $25.55 \pm 2.21$ & $22.17 \pm 1.93$ \\
Acetate $(\mathrm{mmol} / \mathrm{d})$ & $13.49 \pm 1.71$ & $13.38 \pm 0.63$ & $14.50 \pm 0.48$ & $13.32 \pm 1.26$ & $12.63 \pm 0.77$ & $13.84 \pm 1.14$ & $12.62 \pm 1.09$ \\
Propionate $(\mathrm{mmol} / \mathrm{d})$ & $4.63 \pm 0.60$ & $4.67 \pm 0.38$ & $5.05 \pm 0.20$ & $4.77 \pm 0.55$ & $4.47 \pm 0.37$ & $5.14 \pm 0.57$ & $4.40 \pm 0.44$ \\
Butyrate $(\mathrm{mmol} / \mathrm{d})$ & $4.00 \pm 0.54$ & $3.78 \pm 0.39$ & $4.27 \pm 0.25$ & $3.95 \pm 0.39$ & $4.03 \pm 0.27$ & $4.36 \pm 0.42$ & $3.64 \pm 0.32$ \\
$\mathrm{NH}_{3}-\mathrm{N}(\mathrm{mmol} / \mathrm{l})$ & $6.03 \pm 0.29$ & $6.36 \pm 0.07^{\mathrm{a}}$ & $6.06 \pm 0.20$ & $5.89 \pm 0.28^{\mathrm{b}}$ & $5.97 \pm 0.18^{\mathrm{b}}$ & $6.29 \pm 0.24$ & $6.06 \pm 0.13$ \\
OMD $(\%)$ & $41.17 \pm 4.10$ & $40.40 \pm 2.07$ & $40.40 \pm 3.51$ & $39.20 \pm 6.87$ & $38.00 \pm 2.92$ & $40.60 \pm 2.51$ & $38.00 \pm 3.96$ \\
\hline
\end{tabular}

${ }^{\mathrm{a}, \mathrm{b}}$ Means within the same row with different superscript differ $(\mathrm{p}<0.05)$.

and oven temperatures were 220,250 , and $130^{\circ} \mathrm{C}$, respectively. Daily production rates of SCFA were estimated by multiplying the respective concentration by the volume of effluent collected. Ammonia $\mathrm{N}$ was measured using the steam distillation method of Kjeldahl (20). The ruminal digestibility of organic matter (OMD) was analyzed using the technique described by Orskov et al (16).

\section{Statistical analyses}

The means of values from treatments were compared by one-way analysis of variance (Sigmastat 3.1; Systat Software, Erkrath, Germany). The tables show the group means and the standard division ( $\pm \mathrm{SD}$ ). When the differences in treatment means were significant at the probability level of $p<0.05$, they were compared by using Duncan's multiple range test.

\section{Results}

In this study, the addition of topinambur powders up to $1.0 \mathrm{~g} /$ day to a hay : concentrate $(60 \%: 40 \%)$ diet did not have any effects on the basal parameters of rumen fermentation in vitro except for $\mathrm{NH}_{3}-\mathrm{N}$ concentration (Table 3).

The ruminal $\mathrm{pH}$ values were in the normal range $(7.06 \pm 0.04$ and $7.09 \pm 0.03)$ in both control period and control fermenter. Addition of different doses of topinambur powders caused no statistically significant effects $(p=0.37)$ on ruminal $\mathrm{pH}$. Productions of individual (acetate, propionate and butyrate) and total SCFA were not significantly effected by addition of topinambur powders $(\mathrm{p}>0.05)$. A trend toward lower $\mathrm{NH}_{3}-\mathrm{N}$ concentrations was noticed after all doses of topinambur powder; however, this decrease was only significant $(p<0.05)$ after dose 0.4 and $0.6 \mathrm{~g} /$ day. Addition of 0.4 and $0.6 \mathrm{~g} /$ day topinambur powder reduced $\mathrm{NH}_{3}-\mathrm{N}$ concentration by 6 and $7 \%$, respectively, compared to the control fermenter. The digestibility of organic matter was not statistical $(p=0.67)$ influenced by topinambur powders.

\section{Discussion and Conclusion}

Topinambur, where the tubers contain high proportions of the fructan 'inulin', is known as a precursor of a prebiotic in dairy products for human nutrition and as a feed for piglets while studies in ruminants are very limited so far $(9,12)$. However, current opinion contends that inulin can be digested and metabolized in the rumen ecosystem (4). In the present experiment, no clear effect of inulin on ruminal $\mathrm{pH}$ was noticed, in spite of relatively high doses of topinambur powders. This result can be explained by two mechanisms. Firstly, the microbial breakdown of polymeric fructans to fructose is a relatively slow process (2). A relatively slow release of fructose is desirable in order to avoid a rapid drop in $\mathrm{pH}$. Secondly, the Rusitec system used in this study was buffered with the high buffer capacity solution and may not have been appropriate to study the effect of inulin on ruminal $\mathrm{pH}$. The reason of unaffected production rates of SCFA could also be explained by slow ruminal breakdown of inulin.

When compared with the control fermenter, topinambur powders resulted in a deacresed ruminal $\mathrm{NH}_{3}-\mathrm{N}$ concentration. The finding from this study agreed with Biggs and Hancock (2), Lee et al. (13) and Öztürk and Breves (17). The fermentation of carbohydrates affects nitrogen metabolism in the rumen. It has been reported that ammonia concentration in the gut lumen can be reduced by active carbohydrate fermentation, which stimulates the bacterial requirement for nitrogen due to an enhanced growth (11). The decreased $\mathrm{NH}_{3}-\mathrm{N}$ concentration in the rumen can be attributed to a decreased proteolysis, an increased absorption of $\mathrm{NH}_{3}-\mathrm{N}$ from the rumen, an increased turnover rate of rumen fluid and a decreased $\mathrm{NH}_{3}-\mathrm{N}$ utilization by the rumen microorganisms (10). In the Rusitec system $\mathrm{NH}_{3}-\mathrm{N}$ concentration is determined only by the protein breakdown and by the $\mathrm{NH}_{3}-\mathrm{N}$ utilization of rumen microorganisms. The decrease in $\mathrm{NH}_{3}-\mathrm{N}$ concentration might have been the result of increased incorporation of ammonia into microbial protein. 
The digestibility of organic matter was not statistically influenced by the addition of inulin powders. Two main different pathways of metabolic activity can be maintained by organic matter degradation in rumen microbes (14). Firstly, the growth rate of the microorganisms determined by microbial protein synthesis, and secondly, fermentation rate determined by SCFA production. Since the digestibility of organic matter was unchanged in the presence of topinambur powders, the lower ammonia concentrations were indicators that the added inulin was preferably digested by the rumen microflora as additional substrates for metabolic purposes.

In vitro $\mathrm{NH}_{3}-\mathrm{N}$ reducing effect of inulin could be of great value in increasing microbial growth and avoiding accumulation of ammonia in the rumen in vivo. Moreover, additional research is necessary to clarify the potentially beneficial effects of inulin on rumen metabolism.

\section{Acknowledgments}

I am grateful to G. Becker and M. Burmester for their skilled technical assistance.

\section{References}

1. Bergen, WG, Bates DB (1984): Ionophores: their effect on production efficiency and mode of action. J Anim Sci, 58, 1465-1483.

2. Biggs DR, Hancock KR (1998): In vitro digestion of bacterial and plant fructans and effects on ammonia accumulation in cow and sheep rumen fluids. J Gen Appl Microbiol, 44, 167-171.

3. Böhm A, Kaiser I, Trebstein A, Henle T (2005): Heatinduced degradation of inulin. Eur Food Res Technol, 220, 466-471.

4. Chesson A, Forsberg CW (1988): Polysaccharide degradation by rumen micro-organisms. 251-284. In: PN Hobson (Ed), The Rumen Microbial Ecosystem, Elsevier Applied Science, London and New York.

5. Czerkawski JW, Breckenridge G (1977): Design and development of long-term rumen simulation technique (RUSITEC). Br J Nutr, 38, 271-384.

6. Fischbein L, Kaplan M, Gough M (1988): Fructooligosaccharides: a review. Vet Hum Toxicol, 30, 104107.

7. Gibson GR, Roberfroid MB (1995): Dietary modulation of the colonic microbiota: introducing the concept of prebiotics. J Nutr, 125, 1401-1412.

8. Havenaar R, Marol-Bonin S, Van Dokkum W, Petitet S, Shaafsma G (1999): Inulin: Fermentation and microbial ecology in the intestinal tract. Food Rev Int, 15, 109-120.

9. Hindrichsen IK, Wettstein HR, Machmüller A, Bach Knudsen KE, Madsen J, Kreuzer M (2006): Digestive and metabolic utilisation of dairy cows supplemented with concentrates characterised by different carbohydrates. Anim Feed Sci Technol, 126, 43-61.
10. Höller H, Breves G, Martens H (1983): Non-proteinnitrogen and reduced phosphorus supply to sheep, I. Phosphorus, volatile fatty acids, $\mathrm{NH}_{3}$ and $\mathrm{pH}$ of rumen liquid and daily fluid and phosphorus outlow from the rumen. 81-87. In: Nuclear Technique for Assessing and Improving Ruminant Feeds, IAEA, Vienne.

11. Jorgensen $\mathbf{H}$, Zhao XQ, Theil PK, Gabert VM, Bach Knudsen KE (2003): Energy metabolism and protein balance in growing rats fed different levels of dietary fibre and protein. Arch Anim Nutr, 57, 83-98.

12. Kasperowicz A, Michalowski T (2002): Assessment of the fructanolytic activities in the rumen bacterium Treponema saccharophilum strain S. J Appl Microbiol, 92, $140-146$.

13. Lee MRF, Merry RJ, Davies DR, Moorby JM, Humphreys MO, Theodorou MK, MacRae JC, Scollan ND (2003): Effect of increasing availability of watersoluble carbohydrates on in vitro rumen fermentation. Anim Feed Sci Technol, 104, 59-70.

14. Leng RA (1982): Modification of rumen fermentation. 427-453. In: JB Hacker (Ed), Nutritional Limits to Animal Production from Pastures. Farnham Royal, Commonwealth Agricultural Bureaux.

15. Niness KR (1999): Inulin and oligofructose: What are they? J Nutr, 129, 1402-1406.

16. Orskov ER, Hovell FDDeB, Mould F (1980): The use of nylon bag technique for the evaluation of feedstuffs. Trop Anim Prod, 5, 195-213.

17. Öztürk H, Breves G (2005): Effects of the prebiotic inulin on in vitro ruminal microbial metabolism. Proceedings of the Society of Nutrition Physiology, Hohenheim-Stuttgart, Germany, 14, 157.

18. Patkia G, Barta J (2000): Carbohydrate composition of different Jerusalem artichoke varieties. Abstracts of 4th International Fructan Symposium "Fructan 2000". August 16-20, 2000. Arolla. Switzerland. P.2.10.

19. Roberfroid MB, Van Loo JAE, Gibson GR (1998): The bifidogenic nature of chicory inulin and its hydrolysis products. J Nutr, 128, 11-19.

20. Stuck K, Faul K, Hylla S, Stein J, Breves G (1995): The application of a semi-continuous colon simulation technique (COSITEC) for studying the effects of clindamycin on microbial hindgut metabolism. Z. Gastroenterol. 33, 241-246.

21. Wang X, Gibson GR (1993): Effects of the in vitro fermentation of oligofructose and inulin by bacteria growing in the human large intestine. J Appl Bacteriol, 75, 373-380.

Geliş tarihi: 20.09.2007 / Kabul tarihi: 09.11.2007

Address for correspondence

Dr. Hakan Öztürk

Ankara University, Faculty of Veterinary Medicine

Department of Physiology

Diskapi 06110 Ankara - Turkey

e-mail:Hakan.Ozturk@veterinary.ankara.edu.tr 